Akın, E. S.; Özen, H. / Sosyal Bilimler Araştırmaları Dergisi. I, (2013): 23-48

\title{
Tarihi Yapılarda Yeniden Kullanım Sorunları Tokat Meydan ve Sulu Sokak
}

\section{Emine Saka Akın ${ }^{1}$, Hamiyet Özen ${ }^{2}$}

\section{Özet}

Günümüzde farklı coğrafik alanlarda ve kültürlerde küreselleşmenin yansımaları olarak geçmişten koparılmış, kültürel mirasını yansıtmayan ve birbirlerine benzeyen kentlerin sayısı artmaktadır. Dolayısıyla, küreselleşmenin etkisi altında bozulan kentlerin kimliklerinin korunması ve yaşatılması günümüzün önemli kentleşme sorunlarından birisidir.

Küreselleşen dünyada eski kent kimliklerinin kaybolmasındaki nedenler arasında yaşam koşulları ve teknolojik değişimler önemli bir yer tutmaktadır. Değişen ve gelişen kentlerde yeni işlevlere ihtiyaç duyulmakta ve bu işlevlere göre kentler şekillenmektedir. Bu şekillenmeler devam ederken eski kentleri oluşturan yapı ve yapı grupları yeni işlevlere cevap veremediğinden terk edilme sürecindedir. Aynı zamanda eski mekânlar yeni yapıların baskısı altındadır.

Tarihi yapıları yeni yaşam alanları ve biçimleriyle bütünleştirmen en iyi yöntemlerinden birisi, onlara yeni bir hayat vermektir. Yapı için güncelliğini kaybetmiş işlevinin yerine yeni işlev vermek yeni bir yaşamın başlangıcıdır. Tarihi yapılarda yeniden kullanım sorunlarının irdelendiği bu çalışmada Anadolu'da pek çok uygarlığa ev sahipliği yapmış Tokat Kenti örnek olarak alınmıştır. Kentte yeni işlev verilmiş ya da sadece onarılmış restorasyon uygulamaları devam etmektedir. Hem literatür hem de alan çalışması şeklinde yürütülen bu çalışmada, seçilen örnekler üzerinden koruma ve yeniden kullanım sorunlarının analiz edilmesi hedeflenmiştir.

Anahtar Kelimeler: Küreselleşme Yeniden Kullanım, Restorasyon, Kimlik, Tokat.

\section{Re-use problems of Historical Building in Meydan and Sulu Street of Tokat}

\author{
Abstract \\ Today, the number of cities in various geographical regions and cultures \\ resembling to each other and detached from their past are increasing as reflections of

\footnotetext{
${ }^{1}$ Yrd.Doç.Dr. Gaziosmanpaşa Üniversitesi, Fen Edebiyat Fakültesi, Sanat Tarihi Bölümü, Tokat. eminesaka.akin@gop.edu.tr

${ }^{2}$ Yrd.Doç.Dr. Karadeniz Teknik Üniversitesi, Mimarlık Fakültesi, Mimarlık Bölümü, Trabzon.ozen@ktu.edu.tr
} 
Akın, E. S.; Özen, H. / Sosyal Bilimler Araştırmaları Dergisi. I, (2013): 23-48

globalization. Therefore, conservation and perpetuating the identities of the cities deteriorated by globalization is one of the important today's issues of urbanization

Technological changes and living conditions have important roles in causing the city identity to lose in globalizing world. In developing and changing cities, new functions are needed and the cities are shaped according to these functions. While these shaping processes continue, the buildings and group of buildings constituting the old cities are in the process of being abandoned because of not responding to these new functions. In addition to this, the old places are under pressure of new buildings.

One of the best methods integrating the historical buildings with new living areas and their forms is to give them a new life. Converting the outdated functions of buildings into new functions is a beginning of new life for the buildings. In this study, the city of Tokat that has been home to many civilizations in Anatolia was taken as an example for the evaluating the problems of re-use historic buildings. The applications of converting the buildings into new functions or restorations consisting of only reparations are continuing in the city. This study conducted in the form of both field work and literature aimed to analyze the problems of conservation and adapted reuse on the selected examples of historical buildings.

Key Words: Globalization, Re-use, Restoration, Identity, Tokat

\section{GíRIŞ̧}

Moderleşme sürecine bağlı olarak gelişen küreselleşme olgusunun en belirgin etkileri kentler ve yaşamları üzerinde olmuştur. Kentsel alanlar uygarlığın geliştiği ve toplumsal dönüşümlerin geçekleştĭgi yerlerdir. Ancak günümüzde kürselleşme ve hızlı değişim, kentlerin geçmişten taşıdığ 1 değerleri tehdit altına alan bir sürece girmiştir. Kontrolsüz kentsel gelişmeler, hem yapısal hem de doğal çevrelerinin sağlıksız bir biçimde büyüyüp gelişmesine yol açmaktadır. $\mathrm{Bu}$ bağlamda değişen yaşam koşulları ve teknoloji tarihi nitelikteki kültürel mimari mirasın işlevsel olarak eskimesini hızlı bir biçimde sürdürmektedir.

Zamana bağlı olarak işlevsel ve fiziki olarak eskimiş tarihi yapıların restorasyon ve koruma çalışmaları sadece yapının fiziksel olarak iyileştirilmesi olarak kalmamalıdır. Yaşam döngüsünü devam ettirecek bir işleve göre bakımı ve onarımı yapılmalıdır. Ancak koruma çalışmaları toplumun kültürel yapısına, çevresine ve ihtiyaçlarına uygun bütünsel bir yaklaşımla olmalıdır. Kentlerin yenilenmesinde bir kimlik bilincinden yola çıkan Güvenç (1974), ilk ve temel ilkenin; kentin varlığını, kimliğini, geçmişten geleceğe bir süreklilik olarak 
algılamak ve kavramak olduğunu ifade etmektedir. Yapıya uygun koruma, zamanının gerekçelerine de cevap verebilmeli ve bunu da süreklilik içinde yapmalıdır. Zamanının sürekliliği içinde mimar, yaşamı ve çevreyi güzelleştirmeye çalışırken bunu geçmişe ve geleceğe bağlayan devamlılık içinde yapmalıdır (Erder,1999).

Kentsel mekânlarda yapılan koruma geçmişi dondurmak, çağın insanı için yaşanmaz duruma getirmek koruma olarak nitelendirelemez (Bektaş,1992). Korumada eski ve yenin yan yana bir bütün içinde varlığını sürdürdüğü bir anlayışı benimsemek esas olmalıdır. Eski ve yeniyi birbirinden izole ederek eskiyi korumak zordur. Çünkü bu tutum, tarihi yapıyı bugünün bağlamından soyutlayarak bir kent mobilyası haline getirmektedir (Kuban, 2000). Çevresinden soyutlanan yapı, her geçen gün toplum tarafindan daha az kullanılan önemsiz nesneye dönüşmekte ve ait olduğu kentsel mekânın ve kültürün bir parçası olma niteliğini yitirmektedir (Asiliskender, 2005). Çağdaş koruma kavramı bilgiden estetiğe, halkın bilincinden ahlaka, parasal kaynaklardan politikalara kadar geniş bir kapsama sahip olmak zorundadır. Ya da etkinlik alanı olarak çağdaş korumada; her türlü korumanın temelde bütünleşmesinden yeniden kullanım için değiştirilmesine, arkeolojik korumadan kentsel yenilemeye, peyzaj düzenlemeden doğal çevre korumasına, mimarlık alanı içindeki her çeşit ürünün yenilenmesine, bakımına, onarımına kadar var olan yöntemlerin, kuramların ve uygulamaların birbiriyle dolayl1-dolaysız ilişkileri bulunmaktadır (Görgülü,1993).

Dolayısıla Amsterdam Bildirgesi'nde (1975) ilk defa gündeme getirilen bütünleşik koruma yaklaşımı başarılı koruma uygulamaları için benimsenmelidir. Bu bildirgeyle tüm ulusların ortak malı olduğu vurgulanan mimari miras, günümüzde ülkelerin üzerinde önemle durduğu, sorunlarına çözüm getirmeye çabaladığı bir alan halini almıştır (Akın, 1998). Madran (2009), korumada noktasal çözümlerden ziyade bütünleşik koruma politikaların, uluslar arası kuram ve kavramların benimsenmesini, ancak Türkiye'nin kendine özgü değer ve koşullarına göre uyarlanması gerektiğini ifade etmektedir.

Yaşatarak koruma yaklaşımı toplumu etkileyici ve eğitici, onları yüceltici birer anlam kazandırmanın en etkin yoludur. Önemli olan yapıları yaşayan birer varlık konumuna getirebilmektir. Bu ancak yapıya bir işlevsel içerik kazandırmak, onu topluma yararlı kılmak, toplumun onda yaşamasını, çevrenin ondan yararlanmasını sağlamakla mümkündür (Altınoluk, 1998). Günümüzde tarihi yapı ve çevrelerinin korunması bir zorunluluktur. Çünkü 
değişme hızı içinde, eski ve yeninin ortak yaratacakları yeni bir bütünün oluşturulması için bu gereklidir (Kuban, 2000). Günümüzde tarihsel çevrenin korunmasında takınılacak tavır ise belirlenecek ilkeler ve hedefler doğrultusunda geçmişten gelen değerleri geleceğe aktarmak olmalıdır (Kiper, 2006).

Tokat, tarihi M.Ö. 5500'lere inen, sirasıyla Comana Pontica (Komana), Med, Pers, Helenistik, Pontus, Roma (Texier, 2002) çağlarında varlı̆̆ını sürdürmüş, Bizans, Danişmend, Anadolu Selçuklu, İlhanlı ve Osmanlı medeniyetlerine ev sahipliği yapmış bir kenttir. Bütün bu medeniyetlerin izlerini taşıyan kentte son yıllarda restorasyon çalışmaları hız kazanmasına karşın, yapılan restorasyonlar ile anıtsal yapıların yeniden kullanılması konusunda ciddi sorunlar gözlemlenmektedir. Bu çalışmada örnek alan olarak seçilen Tokat Meydan ve Sulu Sokak'ta restore edilen anıtsal yapıların yeniden kullanımları üzerine saptama ve önerilerin geliştirilmesi amaçlanmıştır.

\section{2.Çalışma Alanı}

Anadolu Selçuklu Dönemi'nde, Anadolu'nun 6. büyük şehri olan Tokat doğu-batı yönündeki ticaret kervanlarının konakladığı kervansaraylar, hanlar ile düzenli yol ve köprülerin inşa edildiği ekonomik ve ticari hayatın gelişmiş olduğu bir kentti (Baykara, 2004). Süreyya Faroqhi (1994), 16. Yüzyılda Afyon, Tokat ve Beypazarı'nda kayıtlara geçmiş olan 5-6 hanın bulunduğunu, Tokat ve Afyon'un bölgelerarası ticaret merkezi olduğunu belirtmektedir.

Tokat kentinin en eski ticaret merkezi kalenin güneyinde bulunan Sulu Sokak ve çevresidir. Zamanla büyüyen kent Anadolu Selçuklu ve Osmanlı Dönemi'nde 3 önemli alan oluşturmuştur (Şekil 1), (Akın, 2009). Biri Sulu Sokak ve çevresi (Şekil 2), diğeri günümüzde Cumhuriyet Meydanı denilen Ali Paşa Camii ve çevresi, üçüncüsü de Hatuniye (Meydan) Camii, Taşhan ve Gökmedrese arasında kalan alandır (Şekil 3). Ali Paşa ve çevresinde 1914 yılında çıkan bir yangınla bu alandaki birçok yapı yok olmuştur (Beşirli, 2001). Dolayısıyla, çalışmada bu alan ele alınmamıştır. 
Akın, E. S.; Özen, H. / Sosyal Bilimler Araştırmaları Dergisi. I, (2013): 23-48

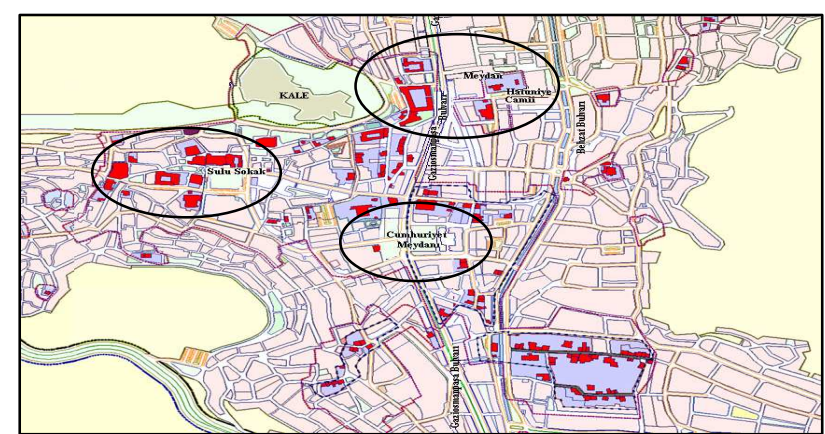

Şekil 1. Tokat tarihindeki üç önemli alan (Akın, 2009).
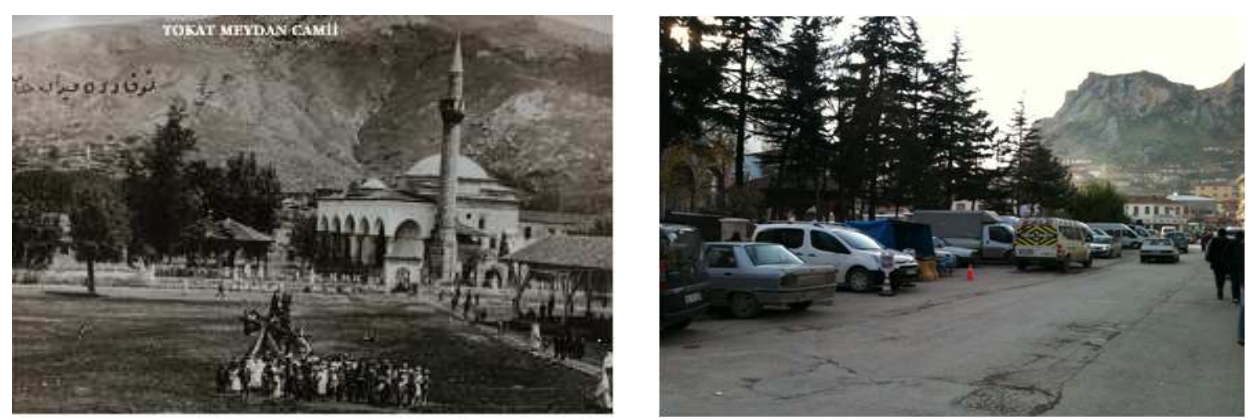

Şekil 2. Meydan eski (Erdem, 2007) ve günümüz görüntüsü (Akın, 2012).
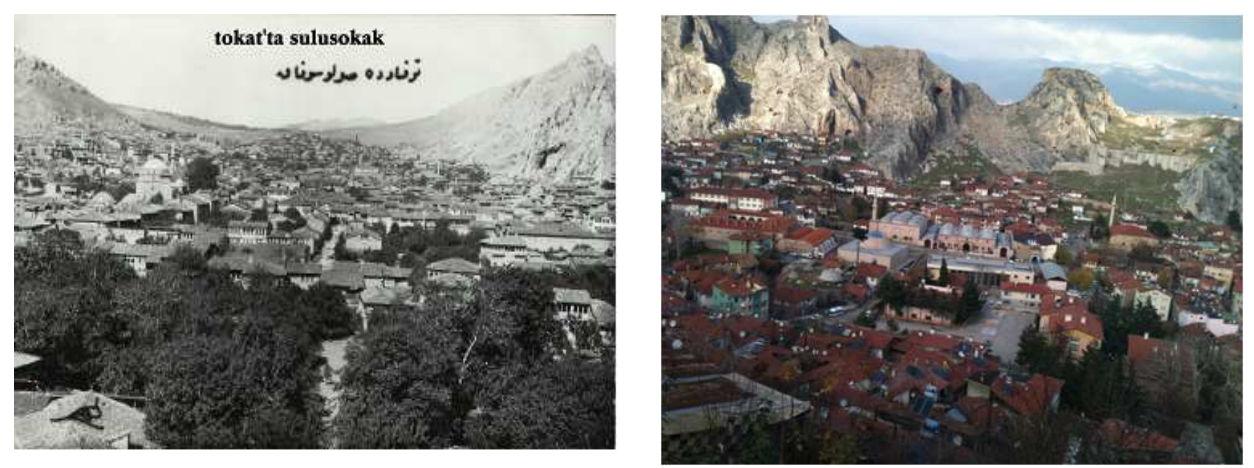

Şekil 3. Sulu Sokak eski (Erdem, 2007) ve günümüz görüntüsü (Akın, 2012). 


\subsection{Meydan Bölgesi: Kentin Toplanma Noktası}

Halk arasında "Meydan" adı ile anılan ticaretin yoğun olduğu ve eski dönemlerde panayırların kurulduğu alandır. Günümüzde alanı çevreleyen yapılar arasında fiziki ve mekânsal bağlar yoktur. Bu yapıların etrafında gelişen çarpık ve plansız ticaret ve konut dokusu tarihi yapıların algılanmalarını güçleştirmektedir (Şekil 4).

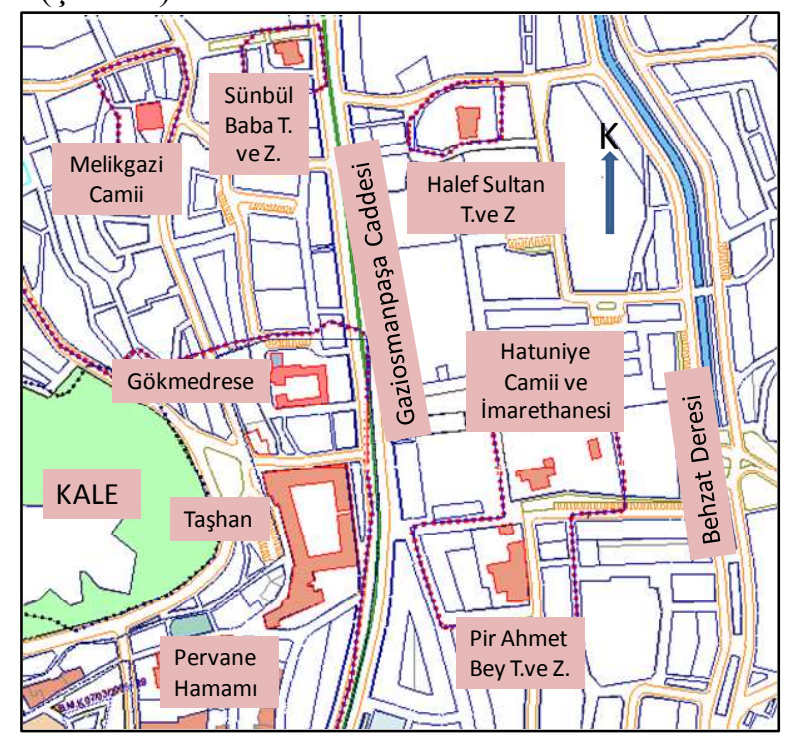

Şekil 4. Meydan ve çevresi (Akın, 2009).

Tarihi merkezde bulunan bu yapıların bir arada bulunuşları ve konumlanışları kentin geçmişini günümüze taşıyan önemli özellikleridir. 1800 yılların sonunda birçok yapının yıkımı ile yapılan ve günümüzde kentin ana trafik arterini oluşturan Gaziosmanpaşa Caddesi tarihi merkezi ikiye bölmüştür. Bölünme tarihi merkezin bütüncül bir şekilde planlanmasına engel teşkil etmektedir. Halen mevcut olan anıtsal yapılar ve tarihi arka plan göz önünde bulundurulunca bu alanın günümüz kent planlaması ve kentsel yaşamında büyük bir önemi olduğu anlaşılmaktadır. Bu alandaki tarihi yapılar (Şekil 5);

Hatuniye (Meydan) Cami; Sultan II. Mehmet tarafından Tokat'ta annesi adına yaptırılan caminin kapısı üzerindeki kitabesine göre 1485 tarihlidir (Aslanapa, 2004). Hatuniye Cami plan ve hacim biçimlenişi açısından klasik dönemde çok karşılaşılan tek kubbeli anıtsal cami tipinin bir varyasyonudur (Uysal, 1986). 1939 depreminde son cemaat yerine kadar yıkılmış, kubbeleri hasar görmüştür ve kullanılamayacak hale gelmiştir. Bu yapının restorasyonu halk tarafindan 1953 yılında yapılmıştır. Yapı daha sonra 1999'da Vakıflar 
Akın, E. S.; Özen, H. / Sosyal Bilimler Araştırmaları Dergisi. I, (2013): 23-48

Bölge Müdürlügü’nce basit bir onarım geçirmiştir (Akın, 2011). Osmanlı Dönemi'nde yapılan cami halen ibadet yapısı olarak kullanılmaktadır.

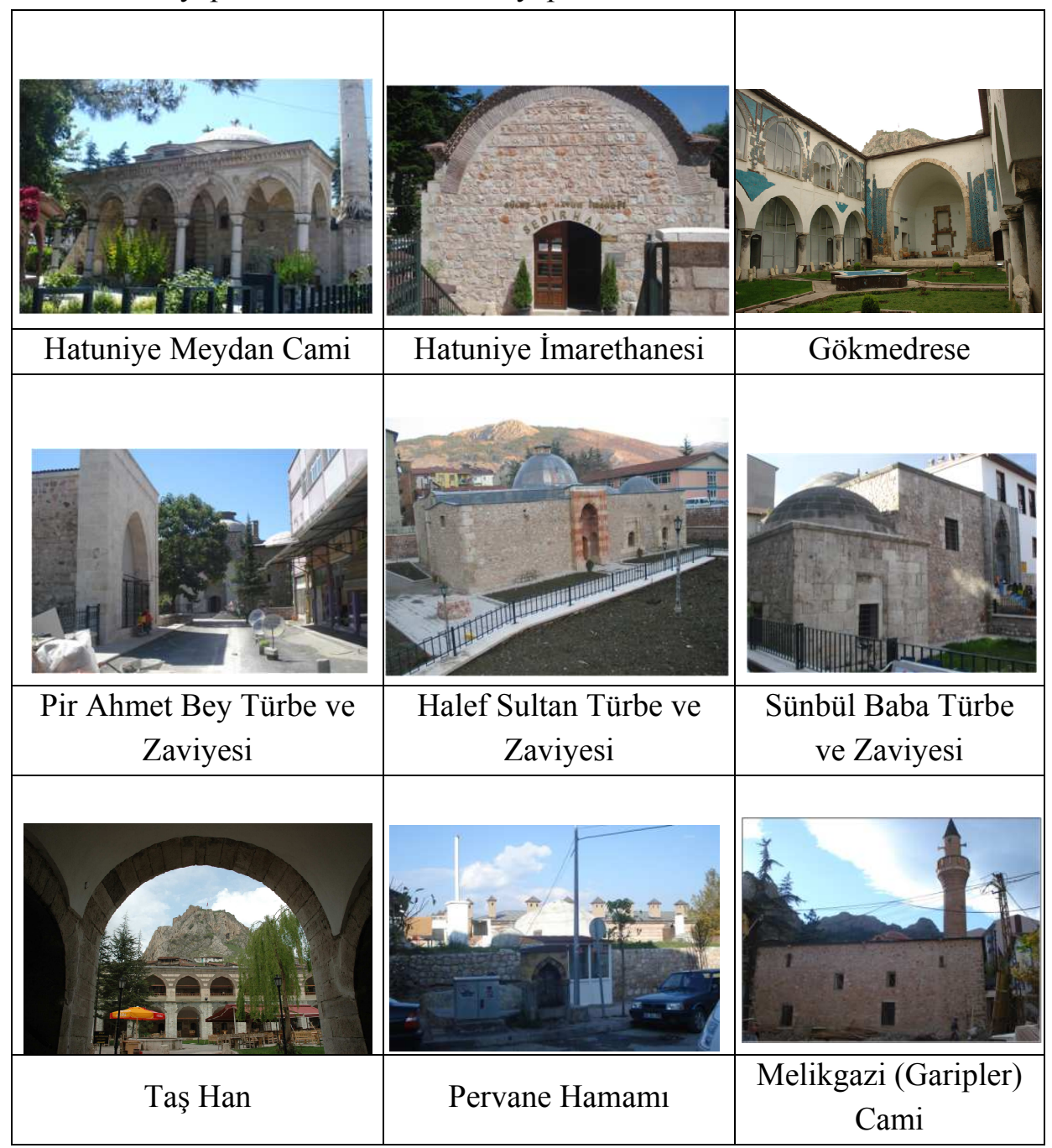

Şekil 5. Meydan bölgesinde bulunan tarihi yapılar (Akın, 2012).

Hatuniye Imarethanesi; Osmanlı Dönemi'nde Hatuniye Cami ile birlikte 15.yüzyılda inşa edildiği düşünülen yapı 1939 depreminde oldukça hasar görmüş ve kullanılmayacak hale gelmiştir. 2005 yllında restorasyonu yapılmış ve halen çay evi olarak kullanılmaktadır. İşlev değişikliği etkin kullanımını arttırmakla birlikte çevresinde bulunan çarpık konut ve ticaret yerleşimi, tabela ve diş eklentiler görsel olarak cephe estetiğine zarar vermektedir. 
Akın, E. S.; Özen, H. / Sosyal Bilimler Araştırmaları Dergisi. I, (2013): 23-48

Gökmedrese; Yapının kitabesinde tarih bulunmamakla birlikte araştırmacılar 1275 tarihinde inşa edildiğini belirtmektedirler. Bir Selçuklu taç kapısının açıldığı eyvan ile karşısındaki ana eyvan ve eksene göre sağ taraftaki geçit eyvanlarıyla üç eyvanlı Anadolu Selçuklu medresesi şemasındadır (Cantay, 1992). İki katlı medresenin beden duvarları moloz taştan inşa edilmiştir, taç kapı kesme taştır (Bakırer, 1981).

2012'ye kadar müze olarak kullanılan yapı Gaziosmanpaşa Bulvarı'nın kenarında olduğu için kentli tarafından dış görünüş olarak bilinmektedir. Ancak medreseden ziyade daha çok müze olarak tanınan yapı genellikle turistlerin ziyaret ettiği ve günümüzde işlev verilmeyi bekleyen bir yapıdır.

Taşhan; Osmanlı Dönemi'nde 1631 yılında inşa edildiği düşünülmektedir (Mercan vd., 2003). Kuzey güney konumunda, kesme taş ve tuğladan, dikdörtgen ve iki katlı inşa edilen hanın ortasında, büyük bir avlu yer almaktadir.

Müze arşivlerinde 1930 yılından bu yana Taşhan'ın bir hayli değişikliğe uğradığ1 görülmektedir. 1939 depreminden sonra doğu yönündeki revak tonozların ve avlu sundurmanın bir bölümü yıkılmıştır (Yavi, 1986). 2007'de yapılan restorasyonla han son durumunu almış ve orijinal hale getirilmiştir. İşlev düşünülmeden restorasyonu yapılan hana orijinal işlevinden farklı işlev verilmiştir. Han odalar küçük el sanatları dükkânlarının bulunduğu küçük dükkânlara, ortasındaki avlu da çay bahçesine dönüştürülmüştür. $\mathrm{Bu}$ işlevler yapının bütünlügüne uygun olmuştur ve kentli tarafindan yoğun kullanılan bir mekân haline dönüşmüştür.

Pervane Hamamı; 1275 yılında çifte hamam olarak inşa edilen yapının zemin katı bugünkü sokak kotundan takriben $3 \mathrm{~m}$ aşağıda kalmıştır. Yapı en büyük tadilatını 16. yüzyıl sonu veya 17. yüzyıl başlarındaki depremden sonra geçirmiştir (Önge, 1995). Anadolu Selçuklu Dönemi yapısı olan hamam günümüzde de hamam olarak kullanılmaktadır. Yapı yoğun ticaret alanı içinde bulunmasına rağmen yol kotunun altında kaldığ 1 için güçlükle algılanmaktadır.

Sünbül Baba Türbe ve Zaviyesi; Anadolu Selçuklu Dönemi’nde 12911292 tarihleri arasında inşa edilmiştir (Önal, 1996). Zaviyenin giriş kapısı, geniş çerçeveli ve mukarnas yaşmaklı mermer bir taç kapı içinde yer almaktadır. Zaviyenin batı cephesine bitişik geleneksel bir konut bulunmaktadır. Bu evin yapımında muhtemelen batı cephede değişiklikler yapıldığı düşünülmektedir. (Emir, 1994). Orijinalinde eğitim işlevine uygun olarak planlanan yapı, restorasyon sonrası 2012 yılının ortalarına kadar ayakkabı dükkanı olarak 
kullanılmıştır. Bu işlev yapının mekânsal ve mimari özelliklerine uygun değildi. Aynı zamanda dış cephe özellikleri bozulmuş ve kötü bir görüntüye dönüşmüştü. En son yapıya aile danışma bürosu olarak işlev verilmiştir.

Halef Sultan Türbe ve Zaviyesi; Anadolu Selçuklu Dönemi'nde 12911292 tarihleri arasında inşa edilmiştir (Emir, 1994). Taç kapı ile girilen zaviye 2004 yılına kadar toprağa gömülü kalmıştır. Yol kotundan yaklaşık 4-5 m aşağıda olan binanın restorasyonu yapılıp yeni işlev verilmiş ve gençlik merkezi-kütüphane olarak kullanılmaktadır. $\mathrm{Bu}$ işlev hem yapının mimarisine hem de kentin yapısına uygun bir işlev olarak karşımıza çıkmakta ve halen yoğun bir kullanıma sahiptir. Buna karşın yapı yüksek yapılar ve yoğun konut dokusu içinde kaldığı için güçlükle algılanmaktadır.

Melikgazi (Garipler) Cami; Kentin en eski camisidir ve kitabesi yoktur. Ancak 14. Anadolu Vakfiye defterinde, Danişmend Ahmed Gazi'nin Tokat'ta 1074 yılında bu camiyi yaptırdığı kayıtlıdır (Anonim, 2001). Minare ve gövdesinde sırlı ve sırsız tuğlaların birlikte kullanılışı ve özellikle yeşil renkli sırlı tuğlalar 13. yüzyıl sonunda eklenmiş olabileceğini düşündürmektedir (Bakırer, 1981). Danişmend Dönemi'nde inşa edilen yapının restorasyonu 2011 yılında aslına uygun olarak Vakıflar Bölge Müdürlüğü'nce yapılmış ve cami olarak kullanılmaktadır.

Pir Ahmet Bey Zaviyesi; 15. Yüzyılın ilk çeyreğinde inşa edildiği düşünülen yapının girişi, kuzeye bakan sivri kemerli geniş bir eyvan içindedir (Mercan vd., 2003). Restorasyonu yapılmış ve 2012 yılının başlarına kadar aşevi olarak kullanılmıştır. Lokantaya dönüştürülecek yapının restorasyonu bu işleve uygun olarak devam etmektedir.

Pir Ahmet Bey Türbesi; Türbeye ait mezar taşlarındaki tarihlerden, 15. Yüzyılın ilk çeyreğinde inşa edildiği düşünülen Osmanlı Dönemi yapısıdır (Mercan vd., 2003). Eyvan şeklinde dışa açılan türbe; 5.30x7.55 m. ölçülerinde kareye yakın dikdörtgen planlı bir yapıdır.

Tablo 1'de bu yapıların restorasyon ve işlev durumları verilmektedir. 
Akın, E. S.; Özen, H. / Sosyal Bilimler Araştırmaları Dergisi. I, (2013): 23-48

Tablo 1. Meydan Bölgesi Yapıların Restorasyon ve İşlev Durumları.

\begin{tabular}{|c|c|c|c|c|c|c|c|c|}
\hline \multirow[b]{2}{*}{$\begin{array}{c}\text { Yapının } \\
\text { Adı }\end{array}$} & \multicolumn{2}{|c|}{$\begin{array}{c}\text { Restorasyon } \\
\text { Durumu }\end{array}$} & \multicolumn{4}{|c|}{ İşlev Durumu } & \multicolumn{2}{|c|}{$\begin{array}{c}\text { Uygun } \\
\text { İşlev }\end{array}$} \\
\hline & $\begin{array}{c}\text { R. } \\
\text { Edildi }\end{array}$ & $\begin{array}{c}\text { R. } \\
\text { Edilmedi }\end{array}$ & 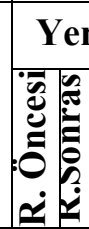 & & Orijinal & Verilmemiş & 包 & 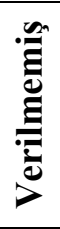 \\
\hline $\begin{array}{c}\text { Hatuniye } \\
\text { İmaretha } \\
\text { nesi }\end{array}$ & $\mathrm{X}$ & & $X$ & & & & $X$ & \\
\hline $\begin{array}{c}\text { Hatuniye } \\
\text { Camii }\end{array}$ & $\mathrm{X}$ & & & & $\mathrm{X}$ & & $\mathrm{X}$ & \\
\hline $\begin{array}{c}\text { Halef } \\
\text { Sultan T. } \\
\text { ve } \\
\text { Zaviyesi }\end{array}$ & $\mathrm{X}$ & & $\mathrm{X}$ & & & & $X$ & \\
\hline $\begin{array}{c}\text { Sünbül } \\
\text { Baba T. } \\
\text { ve } \\
\text { Zaviyesi }\end{array}$ & $\mathrm{X}$ & & & $\mathrm{X}$ & & & $X$ & \\
\hline Taşhan & $\mathrm{X}$ & & & $\mathrm{X}$ & & & $X$ & \\
\hline $\begin{array}{c}\text { Gökmedr } \\
\text { ese }\end{array}$ & $\mathrm{X}$ & & & & & $\mathrm{X}$ & & $X$ \\
\hline $\begin{array}{c}\text { Pir } \\
\text { Ahmet } \\
\text { Bey } \\
\text { Türbe ve } \\
\text { Zaviyesi }\end{array}$ & $X$ & & & $\mathrm{X}$ & & & $X$ & \\
\hline $\begin{array}{c}\text { Melikgaz } \\
\text { i Camii }\end{array}$ & $\mathrm{X}$ & & & & $\mathrm{X}$ & & $X$ & \\
\hline $\begin{array}{l}\text { Pervane } \\
\text { Hamamı }\end{array}$ & $\mathrm{X}$ & & & & $\mathrm{X}$ & & $X$ & \\
\hline
\end{tabular}


Akın, E. S.; Özen, H. / Sosyal Bilimler Araştırmaları Dergisi. I, (2013): 23-48

\subsection{Tarihi Sulu Sokak}

Tarihinde kentin ana ulaşım arteri (doğu-batı) üzerindeki ticaret merkezinin bulunduğu Sulu Sokak ve çevresi ise Tokat kentinin en yoğun anıtsal yapılarının mevcut olduğu bir alandır (Şekil 6). Bu alan Osmanlı Dönemi'nin son zamanlarına kadar kentin ticaret merkeziydi (Özen ve Akın, 2009).

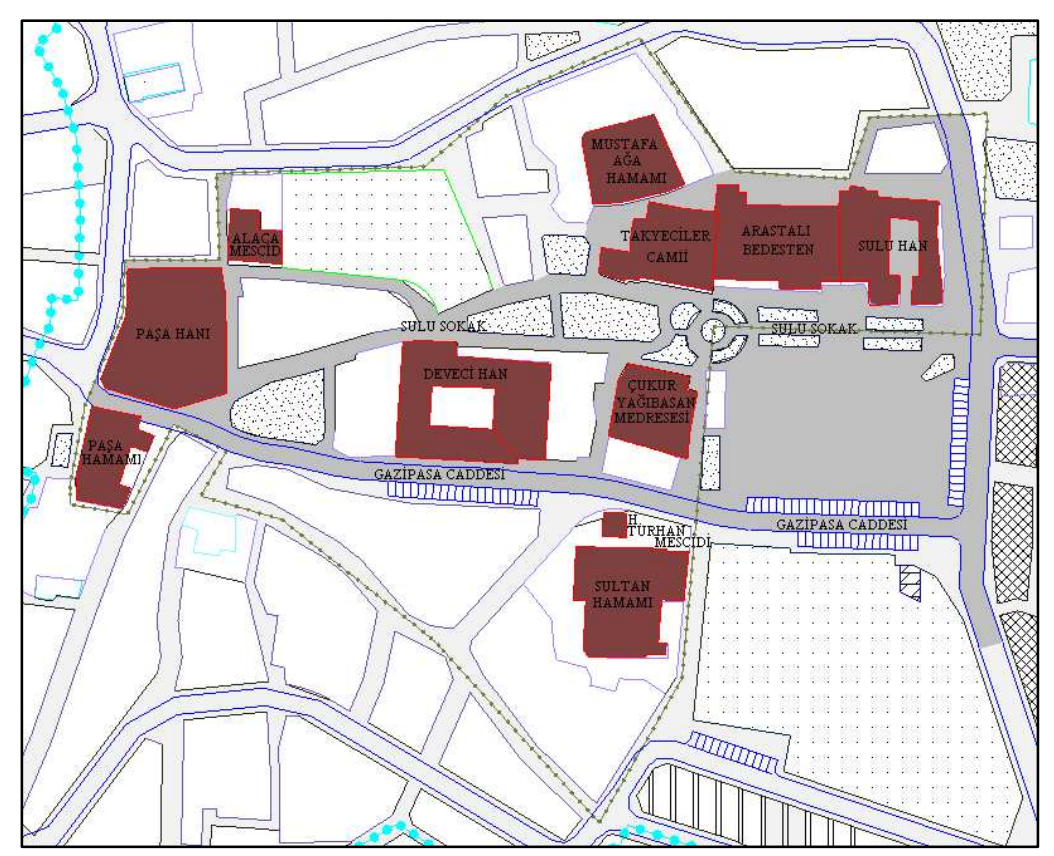

Şekil 6. Sulu Sokak ve çevresi (Özen ve Akın, 2009).

$\mathrm{Bu}$ alan içinde buluna tarihi yapılar (Şekil 7):

Yağıbasan Medresesi; 12. Yüzyıl ortalarında Danişmend Dönemi’nde inşa edilmiştir (Kuran, 1969). Kitabesi 1939 depreminde parçalanmıştır (Yavi, 1986). Tokat Çukur (Yağıbasan) Medresesi ve Niksar (Tokat'ın ilçesi) Yağıbasan Medresesi Türkmen Bölgesi’nde yapılan ve en eski Anadolu medreselerindendir. Diğer kapalı medreselerde olmayan mekânsal özelliği vardır. Konya'da Karatay ya da İnce Minareli gibi ünlü kapalı medreselerde orta hacme açılan eyvanlar kubbe tavanına kadar yükselir ve yapıya tümel mekân etkisi katarlar. Oysa Tokat ve Niksar'da bulunan medreselerde kubbeli merkez basık eyvanlara göre mekân etkisine egemendir (Kuban, 2002). 2006 yılında yeni işlev verilmeden restorasyonu yapılan yapının açık kubbesinin üst kısmı kapanmıştır. 2006 yılından günümüze yeni işlev verilmeyi beklemektedir. 
Akın, E. S.; Özen, H. / Sosyal Bilimler Araştırmaları Dergisi. I, (2013): 23-48

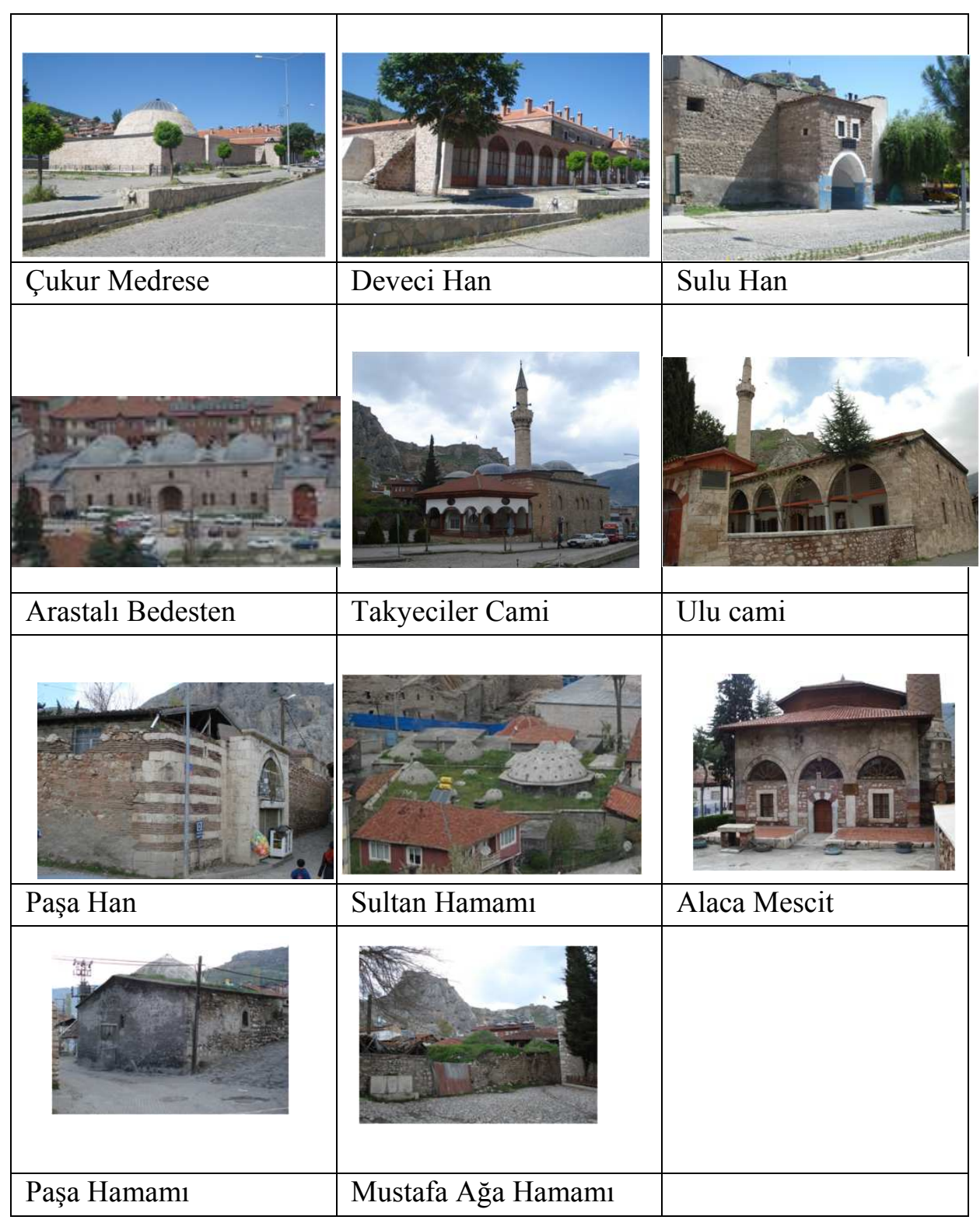

Şekil 7. Sulu Sokak’ta bulunan tarihi yapılar (Akın, 2012). 
Akın, E. S.; Özen, H. / Sosyal Bilimler Araştırmaları Dergisi. I, (2013): 23-48

Deveci Han; Kitabesi bulunmayan yapının mimari planlamasından ve yapı malzemesinden 15 veya 16. yüzyılda inşa edildiği düşünülen bir Osmanlı dönemi yapısıdır (Yavi, 1986).

1939 depreminden sonra oldukça kötü durumda olan yapının 2007 yılına kadar batı cephesine bitişik konutlar vardı. 2007 yılında başlanan restorasyonu hala devam etmekte olan yapının yeni işlevi Güzel Sanatlar Fakültesi idari binası olarak düşünülmüştür.

Sulu Han; Osmanlı Dönemi'nde inşa edilen yapının kitabesi bulunmadığından yapılış tarihi tam olarak bilinmemektedir. 1957 yılında Vakıflar Bölge Müdürlüğü tarafından bir onarım geçirmiştir (Yavi, 1986). Batı cephesi Arastalı Bedestene bitişiktir. Aşevi olarak kullanılan yapı orijinalliğini kaybetmiş ve sadece girişteki taç kapısı ile dikkat çekmektedir.

Arastalı Bedesten; Osmanlı Dönemi'nde inşa edilen yapının tarihi bilinmemektedir. Polonyalı Simeon yapının 16. Yüzyıl sonlarının yapısı olabileceğini söylemektedir (Cezar, 1985). Plan açısından üç hacimli bir yapı olan bedestenin arasta kısmı etrafını çevirmeyip iki yanda uzanmaktadır. Oldukça kötü durumda olan yapının restorasyonu 2008'de tamamlanmıştır. Ancak hiçbir işlev verilmeden restorasyonu yapılan yapıya 2012 yılında müze olarak işlev verilmiş ve müze olarak kullanılmaya başlanmıştır.

Takyeciler Cami; Kareye yakın derinlemesine dikdörtgen planlı ve çok kubbeli bir yapı olan cami 1871-1872 tarihinde inşa edilmiştir. I. Dünya Savaşı yıllarında onarım yapılan caminin kubbe üstleri kırma çatı ile kapanmıştır. 1964-1965 tarihlerinde Vakıflar Genel Müdürlüğü tarafından orijinal durumuna getirilmiştir (Uysal, 1986). Doğu cephesi Arastalı Bedesten'e bitişik olan Osmanlı Dönemi yapısı orijinal işlevinde cami olarak kullanılmaktadır.

Ulu Cami; Bugün doğu cephe kapısı üzerinde 1678 tarihi yazmakta ise de bu tarih onarım tarihine aittir. Caminin Anadolu Selçuklu Dönemi'nde inşa edildiği, fakat yangın, deprem vb. nedenlerle tahrip olan cami IV. Sultan Mehmet zamanında, eski temelleri esas alınarak yeniden yaptııılmıştır (Erdemir, 1986). Baykara (1986), Tokat Ulu Cami'nin kaleye giden yolda olması, kalenin ana giriş kapısına yakın, büyüklüğü ve döneminin Ulu Camilerinin özelliklerini göstermesi bakımından Anadolu Selçuklu ve hatta 
Danişmend Dönemi'ne kadar gittiğini ifade etmektedir. İyi durumda olan yap1 orijinal işlevinde cami olarak kullanılmaktadır.

Paşa Han; 1752 tarihinde Osmanlı Dönemi yapısı olan hanın sadece kesme taştan yapılmış bir portali ve dış duvarları günümüze kadar gelmiştir (Acunsal, 1947). Portalin üst köşelerinde iki hayvan figürü bulunmaktadır. Özel mülkiyette bulunan yapının avlusu içinde hiçbir yapı izi yoktur. Bilinen bir onarım tarihi yoktur.

Sultan Hamami; Hamamın plan tipolojisi 13. Yüzyıldan başlayarak Anadolu'da yoğun olarak görülen bir plan tipine sahiptir. Çifte hamam özelliğine sahip yapının tam olarak inşa tarihi bilinmemektedir. Tahminen 13 . yüzy1l yapısı olduğu düşünülen yapı bugünkü görünümünü 19. yüzyılda almıştır (Eravşar, 2004). Anadolu Selçuklu yapısı olan hamam orijinalliğine uymadan çok kez onarım geçirmiştir. Özel mülkiyette olan yapı hala hamam olarak kullanılmaktadır.

Alaca Mescit; Anadolu Selçuklu zamanında 1300-1301 tarihlerinde inşa edilmiştir (Bakırer, 1981). Daha sonra 1505 yılında minaresinin dışında kalan bölümleri onarım görmüştür (Yavi, 1986). Orijinal işlevinde kullanılan yapının 1939 depremi sonrası minaresinin üst kısmı yıkılmış ve yeniden yapılmıştır (Acunsal, 1947). Orijinal işlevinde cami olarak kullanılmaktadır.

Paşa Hamamı; 1435 tarihli Osmanlı Dönemi yapısıdır. Tek hamam olarak inşa edilen yapı dört eyvanlı, köşe halvetli plan tipindedir (Eravşar, 2004). Uygun olmayan onarımlar geçirmiş yap1 günümüzde kullanılmamaktadir.

Mustafa Ă̆a Hamamı; Çifte hamam olarak yapılan yapının inşa tarihi bilinmemektedir. 1364 tarihli Arapça vakfiyede vakfın gelirleri arasında hamamın ismi geçmektedir. 1970 yılında geçirmiş olduğu onarımda hamamın zemini ve duvarları değiştirilmiş, bunun sonucu olarak sıcaklık bölümü yeterince 1sınmamış ve hamam kullanılmaz hale gelmiştir (Eravşar, 2004). Günümüzde kullanılmayan bu Osmanlı Dönemi yapısı oldukça kötü bir durumdadır. 
Akın, E. S.; Özen, H. / Sosyal Bilimler Araştırmaları Dergisi. I, (2013): 23-48

Tablo 2'de bu yapıların restorasyon ve işlev durumları verilmektedir.

Tablo 2. Sulu Sokak'taki Yapıların Restorasyon ve İşlev Durumları.

\begin{tabular}{|c|c|c|c|c|c|c|c|c|}
\hline \multirow{3}{*}{\begin{tabular}{l} 
Mustafa \\
Ăga \\
Hamam \\
Yapının \\
\multicolumn{1}{c}{ Adı }
\end{tabular}} & \multicolumn{2}{|c|}{$\begin{array}{c}\text { Restorasyen } \\
\text { Durumu }\end{array}$} & & & \multicolumn{2}{|c|}{ İşlev Durumu X } & \multicolumn{2}{|c|}{$\begin{array}{c}\text { Uyg } \\
\text { un } \mathrm{X} \\
\text { İșlev } \\
\end{array}$} \\
\hline & \multirow[b]{2}{*}{$\begin{array}{c}\text { R. } \\
\text { Edildi }\end{array}$} & \multirow[b]{2}{*}{$\begin{array}{c}\text { R. } \\
\text { Edilmedi }\end{array}$} & \multicolumn{2}{|c|}{ Yeni } & \multirow[b]{2}{*}{ Orijinal } & \multirow[b]{2}{*}{ Verilmemiş } & \multirow{2}{*}{\multicolumn{2}{|c|}{ 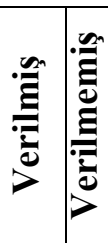 }} \\
\hline & & & 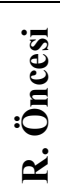 & 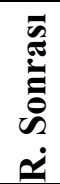 & & & & \\
\hline $\begin{array}{l}\text { Ulu } \\
\text { Camii }\end{array}$ & $\mathrm{X}$ & & & & $\mathrm{X}$ & & $\mathrm{X}$ & \\
\hline $\begin{array}{l}\text { Sulu } \\
\text { Han }\end{array}$ & $\mathrm{X}$ & & & $\mathrm{X}$ & & & & $x$ \\
\hline $\begin{array}{l}\text { Arastalı } \\
\text { Bedeste } \\
\text { n }\end{array}$ & $\mathrm{X}$ & & & $\mathrm{X}$ & & & $\mathrm{X}$ & \\
\hline $\begin{array}{l}\text { Takyeci } \\
\text { ler } \\
\text { Camii }\end{array}$ & $\mathrm{X}$ & & & & $\mathrm{X}$ & & $X$ & \\
\hline $\begin{array}{l}\text { Alaca } \\
\text { Mescid }\end{array}$ & $\mathrm{X}$ & & & & $\mathrm{X}$ & & $\mathrm{X}$ & \\
\hline $\begin{array}{l}\text { Paşa } \\
\text { Han }\end{array}$ & & $\mathrm{X}$ & & & & $\mathrm{X}$ & & $x$ \\
\hline $\begin{array}{l}\text { Paşa } \\
\text { Hamam } \\
\text { I }\end{array}$ & $\mathrm{X}$ & & & & & $\mathrm{X}$ & & $\mathrm{x}$ \\
\hline $\begin{array}{l}\text { Deveci } \\
\text { Han }\end{array}$ & $\mathrm{X}$ & & $\mathrm{X}$ & & & & $\mathrm{X}$ & \\
\hline $\begin{array}{l}\text { Yağıbas } \\
\text { an Med. }\end{array}$ & $\mathrm{X}$ & & & & & $\mathrm{X}$ & & $\mathrm{X}$ \\
\hline $\begin{array}{l}\text { Sultan } \\
\text { Hamam }\end{array}$ & & $\mathrm{X}$ & & & $\mathrm{X}$ & & $\mathrm{X}$ & \\
\hline
\end{tabular}

3. Alanda Yeniden Kullanım Sorunları 
Tarihi kentler anıtsal mimari miras bakımından zengin mekânlardır. Dolayısyla bu anıtlar için yapılan koruma çalışmaları kültür, çevre ve ihtiyaçlar bağlamından soyutlanarak sadece fiziksel onarımlar şeklinde yapılırsa restorasyonu yapılan yapıların kent kullanımına verimli olarak sunulması noktasında aşağıda tanımlanan türden sıkıntılar ortaya çıkabilmektedir.

- $\quad$ Kentsel ölçekte sorunlar

- Yeni işlev verilmeden kaynaklanan sorunlar

\subsection{Kentsel Ölçekte Sorunlar}

1980'li y1llardan sonra, küreselleşme sürecindeki serbestlik, esneklik, kuralsızlık politikaları mekânsal yapıda da kendini göstermiştir. Bunun ülkemiz kentlerine yansıması ise planlı gelişimin neredeyse tamamen terk edilmesi şeklinde olmuştur. Planlamanın değil, piyasanın gereği olarak oluşturulan ve rant doğrultusunda proje tercihleri ile kentsel gelişmeler yönlendirilmektedir. Kamu yönetimleri ise, yerleşme politikalarına ağırlığını koyamayıp bir kuralsızlıklar düzeni içinde sorumluluklarını bile yerine getirememekte, kamusal yetkilerini giderek piyasaya devretmektedir (Kiper, 2006). Ülkenin tamamına hâkim olan bu anlayış, Tokat kentinde benzer şekilde gelişmiştir. Kentin gelişim yönünü kent planlarından çok, çok katlı alışveriş merkezleri ya da mevzi planlarla geliştirilen lüks konut siteleri belirlemektedir. Kent merkezinde bulunan tarihi çekirdek bu nedenlerle giderek yok olmaktadır. Tarihi çekirdeğin korunması, kentliye faydalı kılınmasından çok kent turizminde ne kadar faydalı kılınır öncelikli düşünülen bir olgudur. Oysa tarihi çevre korumanın öncelikli amacı, tarihi yerleşmeyi yok olmaktan kurtarmak, kültür mirasını günümüz yaşamıyla bütünleştirmek olmalıdır (Ahunbay, 2004).

Meydan bölgesi için kentsel ölçekteki sorunlar irdelendiğinde en önemli sorunun alanın kentin ana trafik arteri Gaziosmanpaşa Caddesi ile ikiye bölünmesi olduğu görülmektedir (Şekil 8). Bu cadde ile yapılar arasındaki bütünlük bozulmuş ve birbirinden bağımsız kalmıştır. Birbirlerinden ayrı kalan bu yapıların çoğu, kentin en yoğun ticaret alanında uzun yıllar bakımsız kalarak kullanılmaz hale gelmişlerdir. Vakıflar Bölge Müdürlüğü son 10 yıl içinde bu yapıların büyük bir bölümünü çevresinden kopuk tekil olarak restorasyon yapmıştır. Kentin çöküntü alanı haline gelen bu tarihi merkez halen niteliksiz konut ve ticaret alanı durumundadır. Ayrıca alanın tarihi önemi ve dokusuna aykırı, hızlı ve çarpık yeni yapılaşma süreci kontrolsüz bir şekilde devam etmektedir. Dolayısı ile köhne, bakımsız, çok katlı binalar ve ticaret alanı ile 
çevrelenmiş olan bu tarihi merkez, fiziki olarak algılanmamaktadır (Şekil 9). Şekil 8'de görüldüğü gibi Taşhan ve Gökmedrese arasında yapılan uygun olmayan kütledeki yapı her iki yapının kütlesini ezmekte ve dış cephelerinin algılanmalarını güçleştirmektedir. Yine çarpık ve plansız ticaret ve konut dokusu, köy minibüs duraklarının bu alan içinde olması yoğun bir karmaşaya sebep olmakta ve tarihi Meydanda bulunan anıtsal yapıların algılanmalarını engellemektedir.

Şekil 8. Meydan bölgesinden geçen Gaziosmanpaşa Caddesi ve niteliksiz konut ve ticaret alanları (Akın, 2012).

Anıtsal yapıların yakın çevresinde mevcut olan yapıların ve yerleşmenin iyileştirme ve sağlıklaştırma yoluna gidilmesi gerekmektedir. Tarihi yapıların tek başlarına restorasyonu ve işlevlendirilmesi sorunu çözmekten öte daha karmaşık bir duruma getirmektedir.
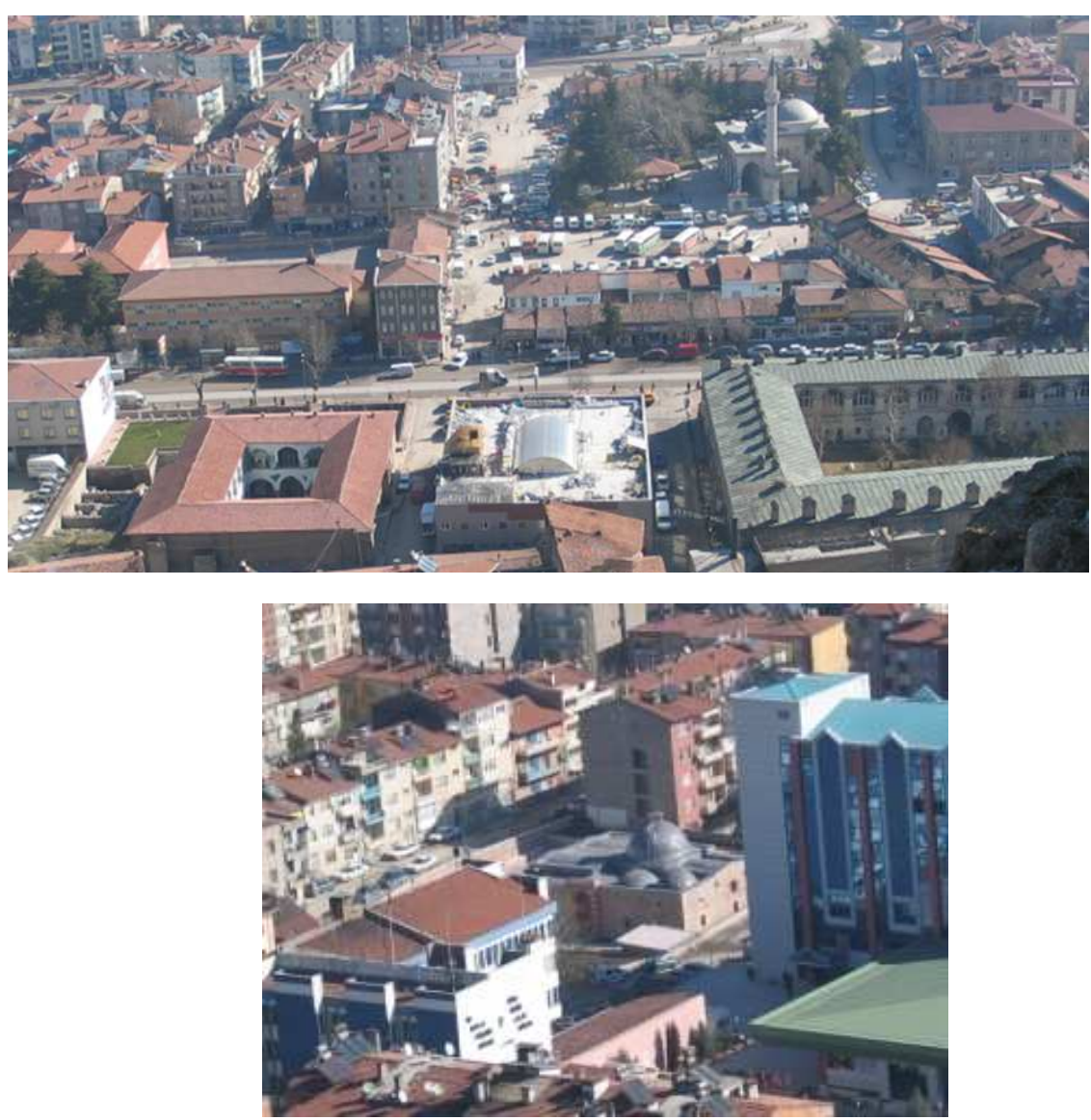
Şekil 9. Çok katlı binalar ve niteliksiz konut alanı içindeki Halef Sultan Türbe ve Zaviyesi (Akın, 2012).

Sulu Sokak için kentsel ölçekteki sorunlar irdelenirse en önemli sorunun bakımsızlık ve terk edilme olduğu görülmektedir. Bu süreç, günümüzde alanın tamamen gecekondu konut yerleşimi içinde kalması sonucunu doğurmuştur. $\mathrm{Bu}$ alanın tekrar değer kazanması ve kentin yaşayan bir parçası olabilmesi için çevresiyle birlikte yapılara farklı işlevler verilerek alanın tarihi yüzünün ortaya çıkarılması sağlanmalıdır. Ayrıca çarpık bir kentleşmenin sonucu olarak bu tarihi alanda kontrolsüz ve bilinçsiz bir şekilde yeni yapılaşma sürmektedir. Sulu Sokak'ta Yağıbasan Medresesi yanında, Arastalı Bedesten karşısında yeni yapılan Vakıf İşhanı bu alandaki yapıları kütlesel olarak ezmektedir (Şekil 10).
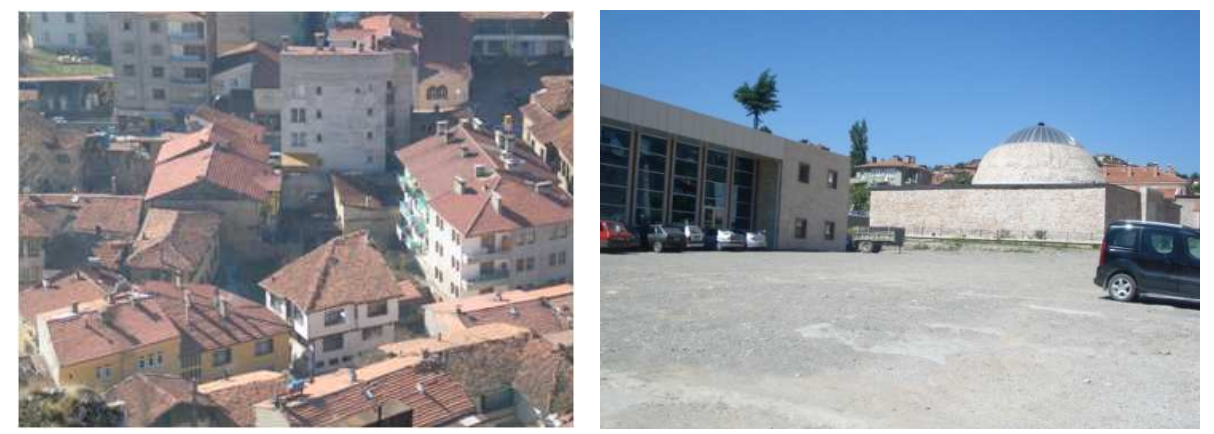

Şekil 10. Sulu Sokak'ta gecekondu konut yerleşimi ve yeni yapılan bina (Akın, 2012).

\subsection{Yeni İșlev Verilmeden Kaynaklanan Sorunlar}

Meydan ve Sulu Sokak çevresinde yapılan restorasyon çalışmaları salt yapının fiziksel onarımından öteye gidememektedir. Planlama ve yeni işlev verilme sürecinde yapıların en çok karşılaş̧ıkları sorunlar; restorasyondan sonra işlev verilmesi ve uygun işlev verilmeyip tekrar işlev değişikliği olarak göze çarpmaktadır. Restorasyon yapıldıktan sonra işlev verilmeye çalışılan yapılar verilen işleve göre yeniden bir onarım sürecine girmektedir. Aynı şekilde orijinal mekânsal kurguya ve mimari yapıya uygun olmayan işlevler değiştirildiğinde de yapı tekrar bir onarım sürecine girmekte ve daha çok zarar görmektedir. Çünkü yeni işlevler, yeni mekânsal düzenlemeler ve ekleri de beraberinde getirmektedir. Özellikle cephe estetiğini ve oranlarını bozan 
eklentiler yapının bütünlüğünü bozmaktadır. Ayrıca eklentilerde malzeme ve yapım sistemi seçimi de önemli bir faktördür. Bu konuda da tutarlı bir yaklaşım sergilenmesi gereklidir. Bu yaklaşım ya zıtlık ya da uyum şeklinde olabilir.
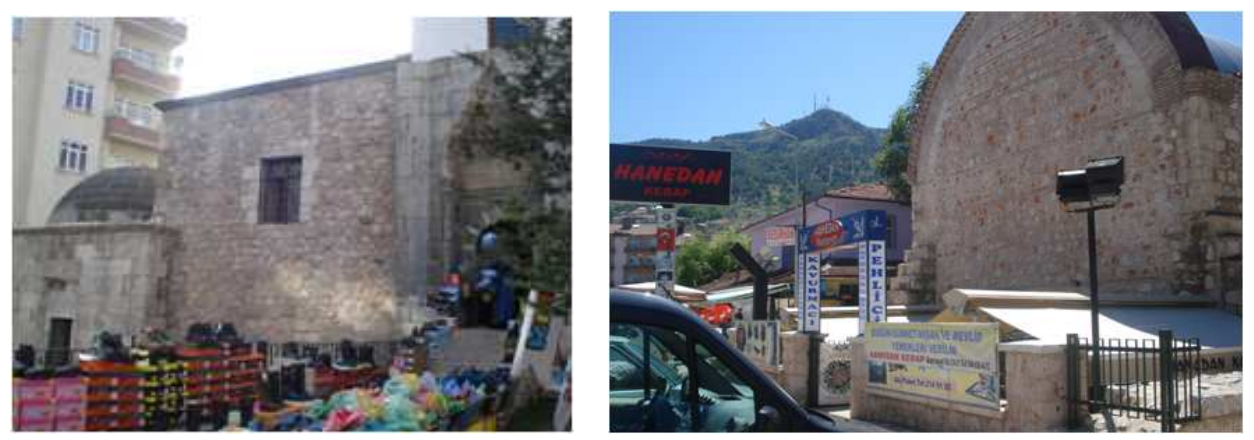

Ayrıca uygun olmayan işlevler Şekil 11'de görüldüğü gibi dış cephe görüntüsünü oldukça bozmaktadır. Aynı zamanda yoğun ticaret alanlarında bulunan bu yapıların dış cephelerindeki tabelalandırmalar çoğu zaman yapıların büyüklüğünü ezmektedir.

Şekil 11. Tarihi yapıların cephe görüntülerini bozan kötü görünümler (Akın, 2012).

Meydan Bölgesi'nde bulunan Taşhan uzun y1llar farklı işlev değişiklikleri geçirerek günümüze kadar gelmiştir. Uygun bir restorasyon ve uygun bir işlev verilemediğinden 1997- 2007 tarihleri arasında kapısı kapalı, kentten kopuk bir dönem geçirmiştir. Gökmedrese uzun yıllardır müze olarak işlevlendirilmiş ve halk arasında medrese olduğu unutulup müze olarak anılmaya başlamıştır. Medrese içinde yeterli mekâna sahip olmayan müze 2012 y1lında Arastalı Bedestene taşınmıştır. Şu anda yeni işlev beklemektedir.

Sulu Sokakta bulunan Arastalı Bedesten'in restorasyonu işlev verilmeden yapıldığından 3 yıl yeni işlev beklemiş ve en son müze olarak işlev verilmiştir. Müze olarak işlevlendirilen yapı yeniden onarım sürecine girmiştir. Yine Yağıbasan Medresesi'nin onarımı 2007'de tamamlanmış ve hala yeni işlev beklemektedir.

$\mathrm{Bu}$ alanların kentin cazibe merkezleri konumuna getirilmeleri için yapılara işlev verilirken o bölgelerin kalkınmalarına yardımcı olacak, gecekondu ve çarpık kent dokularından çıkarılıp kentin kültürel alanlarına dönüş̧ürülmeleri de önemli bir süreçtir. $\mathrm{Bu}$ eylem planlama ve yeni 
işlevlendirme sürecinde ele alınıp çözümlenmelidir. $\mathrm{Bu}$ nedenle yeniden kullanım ile ön plana çıkarılan anıtsal binaların, gerek restorasyonları ve gerekse yeni işlevleri kentin kültür ve sosyal yaşamına göre titizlikle ve bilimsel veriler sonucunda yapılmalıdır.

\section{4.Öneriler ve Değerlendirme}

Korumada istenilen hedefe ulaşmak için tarihi çevrenin yaşam standartlarının yükseltilmesi, tarihi dokuyu bozan trafiğin ve olumsuz baskıların merkezden uzaklaştırılarak yerine kültürel işlevlerin çekilmesi, sürekli bakımı sağlayacak kaynak sorunlarının çözümlenmesi gerekmektedir (Ahunbay, 2004).

Korumay1 gerçekleştirebilmek için yapılan kentsel yenileme çalışmaları, bir stratejiler bütünü dâhilinde gerçekleştirilebilecek bir süreçtir. Bu stratejiler oluşturulduktan sonra uygulamada yerel yönetimlere önemli görevler düşmektedir. Yerel yönetimler, bu görevlerini, alanın sosyo-kültürel, ekonomik ve fiziki-mekânsal niteliklerine göre, farklı kurum ve kuruluşlarla paylaşarak, bir iş bölümü yaparak gerçekleştirmelidirler (Özden, 2001). Bu aşamada kaynaklar üzerindeki baskıları azaltacak ve bütün çevrenin daha iyi algılanmasını sağlayacak ve çevresel kaliteyi yükseltecek planlama önlemlerinin bir bileşkesi olan alan yönetimi gündeme gelmelidir ( Ayrancı ve Gülersoy, 2009).

Alanda yapılan çalışmalar sonucunda Meydan ve Sulu Sokak'ta bulunan anıtsal yapıların sorunları ve bu sorunları çözebilecek öneriler analiz edilerek özetlenmiştir (Tablo 3, 4). Tablo 3 ve 4 'te her iki alanda bulunan tarihi camiler orijinal işlevlerinde kullanıldıklarından dolayı verilmemiştir.

Tablo 3. Meydan Bölgesi'nde bulunan anıtsal yapıların değerlendirilmesi.

\begin{tabular}{|l|lr|l|}
\hline Yapının Adı & \multicolumn{2}{|c|}{ Sorunlar } & \multicolumn{1}{c|}{ Öneriler } \\
\hline & -Gecekondu bölgesinde & -Çevresindeki yapıların \\
& bulunduğu için tarihsel & biçim, tabela ve işlevlerinin \\
& niteliği yitirme & yapıyı ön plana çıarılacak \\
Hatuniye & -Uygun & olmayan & şekilde düzenlenmesi \\
İmarethanesi & tabelalandırma & -Çevresindeki çarpık ticaret \\
& & dokusu en kısa zamanda \\
& & kaldırılmalı \\
& & -Belediyenin kapsamlı \\
& & & meydan projesi hazırlaması \\
\hline Halef Sultan & -Yüksek katlı & yapılar & -Kent dokusu içine sıkışmış \\
\hline
\end{tabular}


Akın, E. S.; Özen, H. / Sosyal Bilimler Araştırmaları Dergisi. I, (2013): 23-48

\begin{tabular}{|c|c|c|}
\hline $\begin{array}{ll}\text { T. } & \text { ve } \\
\text { Zaviyesi }\end{array}$ & arasinda & $\begin{array}{l}\text { yapının tanıtımı daha iyi } \\
\text { yapılmalı }\end{array}$ \\
\hline $\begin{array}{l}\text { Sünbül Baba } \\
\text { T. ve } \\
\text { Zaviyesi }\end{array}$ & $\begin{array}{l}\text {-Yoğun ticaret merkezi } \\
\text { içinde }\end{array}$ & $\begin{array}{l}\text { - Kent dokusu içine sıkışmış } \\
\text { yapının tanıtımı daha iyi } \\
\text { yapılmalı }\end{array}$ \\
\hline Taşhan & $\begin{array}{lcr}\text {-Yanında } & \text { yapılan } & \text { yeni } \\
\text { yapının } & \text { kütlesel } & \text { olarak } \\
\text { binayı ezmesi } & \\
\text {-Gaziosmanpaşa Caddesi'nin } \\
\text { Meydan Bölgesini İkiye } \\
\text { bölmesi }\end{array}$ & $\begin{array}{l}\text {-Bu yapının diğer yapılarla } \\
\text { ve Meydan Bölgesi ile } \\
\text { bütünleşmesini } \\
\text { sağlayabilecek bütünleşik bir } \\
\text { planlamaya gidilmesi }\end{array}$ \\
\hline Gökmedrese & $\begin{array}{l}\text {-Yanında yapılan } \\
\text { yapının kütlesel olarak } \\
\text { binayı ezmesi, } \\
\text {-Gaziosmanpaşa Caddesi'nin } \\
\text { Meydan Bölgesini ikiye } \\
\text { bölmesi } \\
\text {-Uygun işlev verilememesi }\end{array}$ & $\begin{array}{l}\text {-Bu yapının diğer yapılarla } \\
\text { ve Meydan Bölgesi ile } \\
\text { bütünleşmesini } \\
\text { sağlayabilecek bütünleşik bir } \\
\text { planlamaya gidilmesi } \\
\text {-Yapının mimarisine uygun } \\
\text { işlev seçimi }\end{array}$ \\
\hline $\begin{array}{l}\text { Pir Ahmet } \\
\text { Bey Zaviyesi }\end{array}$ & $\begin{array}{l}\text {-Gecekondu bölgesinde } \\
\text { bulunduğu için tarihsel } \\
\text { niteliği yitirme } \\
\text { - Çarpık ve plansız ticaret ve } \\
\text { konut dokusu içinde } \\
\text { bulunması }\end{array}$ & $\begin{array}{l}\text {-Çevresindeki çarpık ticaret } \\
\text { dokusu en kısa zamanda } \\
\text { kaldırılmalı } \\
\text {-Belediyenin kapsamlı } \\
\text { meydan projesi yapması }\end{array}$ \\
\hline $\begin{array}{l}\text { Pervane } \\
\text { Hamamı }\end{array}$ & $\begin{array}{l}\text {-Yapının yol kotu altında } \\
\text { kalmasından } \\
\text { algılanmasının zorlaşması } \\
\text { - Çarpık ve plansız ticaret ve } \\
\text { konut dokusu içinde } \\
\text { bulunması }\end{array}$ & $\begin{array}{l}\text {-Yapıyı açığa çıkaracak yeni } \\
\text { bir restorasyon çalışması } \\
\text { yapılması }\end{array}$ \\
\hline
\end{tabular}


Akın, E. S.; Özen, H. / Sosyal Bilimler Araştırmaları Dergisi. I, (2013): 23-48

Tablo 4. Sulu Sokak'ta bulunan anıtsal yapıların değerlendirilmesi.

\begin{tabular}{|c|c|c|}
\hline $\begin{array}{c}\text { Yapının } \\
\text { Adı }\end{array}$ & Sorunlar & Öneriler \\
\hline Sulu Han & $\begin{array}{l}\text {-Gecekondu bölgesinde } \\
\text { bulunması } \\
\text {-Uygun olmayan işlev } \\
\text { nedeniyle yapıya uygun } \\
\text { olmayan ek ve eklentilerin } \\
\text { yapılması } \\
\text {-Bakımsız cephe }\end{array}$ & $\begin{array}{l}\text {-Yap1 bulunduğu tarihi alanda } \\
\text { diğer yapılarla bir bütün olarak } \\
\text { ele alınarak bölgenin } \\
\text { kalkındırılması sağlanmalı. } \\
\text {-Yeni işlev verilerek } \\
\text { restorasyon yapılması }\end{array}$ \\
\hline $\begin{array}{c}\text { Arastalı } \\
\text { Bedesten }\end{array}$ & $\begin{array}{l}\text {-Gecekondu bölgesinde } \\
\text { bulunmas1 }\end{array}$ & $\begin{array}{l}\text {-Yapı bulunduğu tarihi alanda } \\
\text { diğer yapılarla bir bütün olarak } \\
\text { ele alınarak bölgenin } \\
\text { kalkındırılması sağlanmalı. } \\
\text {-Yapıya uygun işlev verildi }\end{array}$ \\
\hline Paşa Han & $\begin{array}{l}\text {-Gecekondu bölgesinde } \\
\text { bulunması } \\
\text {-Kişisel mülkiyette olması } \\
\text {-Yapının içinin tahrip } \\
\text { edilmesi }\end{array}$ & $\begin{array}{l}\text {-Yapı bulunduğu tarihi alanda } \\
\text { diğer yapılarla bir bütün olarak } \\
\text { ele alınarak bölgenin } \\
\text { kalkındırılması sağlanmalı. } \\
\text {-Yapının kamulaştırılması } \\
\text { sağlanmalı } \\
\text {-Kalan han duvarlarının restore } \\
\text { edilerek uygun işlev verilmesi } \\
\text { sağlanmalı }\end{array}$ \\
\hline $\begin{array}{c}\text { Paşa } \\
\text { Hamamı }\end{array}$ & $\begin{array}{l}\text {-Gecekondu bölgesinde } \\
\text { bulunmas1 } \\
\text {-Kullanılmaz atıl durumda }\end{array}$ & $\begin{array}{l}\text {-Yapı bulunduğu tarihi alanda } \\
\text { diğer yapılarla bir bütün olarak } \\
\text { ele alınarak bölgenin } \\
\text { kalkındırılması sağlanmalı. } \\
\text {-Restoresi yapılıp orijinal } \\
\text { işlevinde kullanılmalı }\end{array}$ \\
\hline $\begin{array}{c}\text { Deveci } \\
\text { Han }\end{array}$ & $\begin{array}{l}\text {-Gecekondu bölgesinde } \\
\text { bulunmas1 }\end{array}$ & $\begin{array}{l}\text {-Yapı bulunduğu tarihi alanda } \\
\text { diğer yapılarla bir bütün olarak } \\
\text { ele alınarak bölgenin } \\
\text { kalkındırılması sağlanmalı. } \\
\text {-Uygun işlevle kullanılması }\end{array}$ \\
\hline
\end{tabular}


Akın, E. S.; Özen, H. / Sosyal Bilimler Araştırmaları Dergisi. I, (2013): 23-48

\begin{tabular}{|c|c|c|}
\hline $\begin{array}{l}\text { Yağıbasan } \\
\text { Medresesi }\end{array}$ & $\begin{array}{l}\text {-Gecekondu bölgesinde } \\
\text { bulunması } \\
\text {-Yapı restore edilmiş olduğu } \\
\text { halde kullanılmamakta }\end{array}$ & $\begin{array}{l}\text {-Yapı bulunduğu tarihi alanda } \\
\text { diğer yapılarla bir bütün olarak } \\
\text { ele alınarak bölgenin } \\
\text { kalkındırılması sağlanmalı. } \\
\text {-Uygun işlev bulunarak } \\
\text { kullanılır hale getirilmeli }\end{array}$ \\
\hline $\begin{array}{c}\text { Sultan } \\
\text { Hamamı }\end{array}$ & $\begin{array}{l}\text {-Gecekondu bölgesinde } \\
\text { bulunması } \\
\text {-Onarımların uygun } \\
\text { olmayışı } \\
\text {-Yapının dış cephesinin } \\
\text { uygun olmayan malzeme ile } \\
\text { kaplanması }\end{array}$ & $\begin{array}{l}\text {-Yapı bulunduğu tarihi alanda } \\
\text { diğer yapılarla bir bütün olarak } \\
\text { ele alınarak bölgenin } \\
\text { kalkındırılması sağlanmalı. } \\
\text {-Dış cephesi orijinal duruma } \\
\text { getirilerek hamam olarak } \\
\text { kullanılmasına devam edilmeli }\end{array}$ \\
\hline
\end{tabular}

Tokat kentinde son dönemlerde yapılan iyileştirme çalışmaları ve planlamalar kapsamında yerel yönetimlerin bu bağlamda yapılar arasında fiziki ve işlevsel bağı güçlendirici çalışma ve planlama uygulamaları olmadığı saptanmıştır. Tarihi yapıların tekil olarak ele alınmasından dolayı, kentsel ölçekte bütüncül bir koruma yaklaşımı mümkün olamamaktadır. Oysaki koruma, özellikle uygulamaya yönelik olarak bir yerel yönetim sorunu olmalıdır (Madran, 2009).

Her iki alanda tarihi yapılar kentsel ölçekte ve tekil olarak uygun olmayan onarımlara, işlev verilmeden yapılan restorasyonlara maruz kalmıştır. Yoğun trafik, gecekondu ve ticaret alanları içinde sıkışmış tarihi yapılar kent ölçeğinde bir bütünün parçası şeklinde bulunmamaktadır. Kentin çöküntü alanlarında bulunan tarihi yapılara verilecek işlevler ve çevrelerindeki yeni planlamalar bir bütün olarak ele alınarak bölgenin kalkındırılması sağlanabilir. Yerel yönetimlerin bu konuda kentsel ölçekteki sorunlara daha bilimsel ve kalıcı düzenleme çalışmalarının olması uygun olacaktır. $\mathrm{Bu}$ bağlamda bütünleşik koruma için yerel yönetimlerin alan yönetimi esaslı planlama yapması daha doğru bir yaklaşım olacaktır. Bütün içinde tarihi yapıların cephe ve mekânsal özelliklerine uygun işlev ve düzenlemelerin yapılarak kentte bu yapıların ön plana çıkarılması ve görünürlügünün sağlanması önemlidir. Kentsel mekânda yapılan her türlü koruma ve yeniden işlevlendirme çalışmaları geçmiş 
Akın, E. S.; Özen, H. / Sosyal Bilimler Araştırmaları Dergisi. I, (2013): 23-48

ve günümüz yaşam koşullarına, kentsel çevreye saygı duyan bütünleşik planlama anlayışı ile yapılmalıdır.

Sonuç olarak, tarihinde Anadolu'nun önemli kentlerinden biri olan Tokat kentinin kültür varlıklarına yapılan restorasyonlarda yeni işlevlerin seçimi ve oluşturulan yeni çevrelerin anıtsal yapılarla ilişkileri kurulurken, bütünleşik koruma yaklaşımıyla ele alınıp yaşatılarak koruma anlayışı çerçevesinde planlama ve uygulama çalışmalarının benimsenmesi amaç olmalidir.

\section{KAYNAKLAR}

Acunsal, F., (1947), Gerçeklerin Diliyle Tokat, Tanin Basınevi, İstanbul.

Ahunbay, Z., (2004), Tarihi Çevre Koruma ve Restorasyon, Yapı Yayın-28, Üçüncü Baskı, İstanbul.

Akın, E.S., (2009), Tokat Kenti Anıtsal ve Sivil Mimari Örneklerinin Analizi ve Değerlendirmesi, Yayınlanmamış Doktora Tezi, K.T.Ü., Trabzon.

Akın, N., (1998), 19. Yüzyılın İkinci Yarısında Galata ve Pera, Literatür Yayınları, İstanbul.

Altınoluk, Ü.,(1998), Binaların Yeniden Kullanımı, I.Bask1, YEM Yayını, İstanbul.

Anonim, (2001), Tokat İl Turizm Müdürlüğü.

Aslanapa, O., (2004), Osmanlı Devri Mimarisi, İnkılap Kitabevi, Anka Basım.

Asiliskender, B., Gökmen, H. ve Yılmaz, N., (2005), Anıt Kavramı, Kimliğin Sürekliliği Değişim: Gevher Nesibe Medresesi Deneyimi, Mimarlık Dergisi, 322:55-59.

Ayranc1, İ. ve Gülersoy, N.Z., (2009), Dosya-14, Tarihi Çevrede Koruma: Yaklaşımlar, Uygulamalar, TMMOB Mimarlar Odası Ankara Şubesi Yayını, Ankara.

Bakırer, Ö., (1981), Selçuklu Öncesi ve Selçuklu Dönemi Anadolu Mimarisinde Tuğla Kullanımı, I. Metin, ODTÜ Mimarlık Fakültesi Basım Atelyesi, Ankara.

Baykara, T., (1986), Tokat Ulu Cami Üzerine Bazı Düşünceler, Türk Tarihinde ve Kültüründe Tokat Sempozyumu, Temmuz, Gelişim Matbaas1, Ankara, Bildiriler Kitab1, 291-294.

Baykara, T., (2004), Türkiye Selçuklularının Sosyal ve Ekonomik Tarihi, IQ Kültür Sanat ve Yayıncılık, Araştırma - İnceleme Dizisi, 69, İstanbul. 
Akın, E. S.; Özen, H. / Sosyal Bilimler Araştırmaları Dergisi. I, (2013): 23-48

Bektaş, C., (1992), Koruma Onarım, Birinci Baskı, YEM Yayını, İstanbul.

Beşirli, M., (2001), 14 Mayıs 191 Tokat Mahkeme Çarşısı Yangını,Tokat Kültür Araştırma Dergisi, Tokat Kültür Araştırma Geliştirme ve Yaşatma Vakfi, Tokat.

Cantay, G., (1992), Anadolu Selçuklu ve Osmanlı Darüşşifaları, Atatürk Kültür, Dil ve Tarih Yüksek Kurumu, Atatürk Kültür Merkezi Yayını, Sayı 61, Ankara.

Cezar, M., (1985), Tipik Yapılarıyla Osmanlı Şehirciliğinde Çarşı ve Klasik Dönem İmar Sistemi, Mimar Sinan Üniversitesi Yayını, No: 9, Milli Eğitim Basımevi, İstanbul.

Emir, S., (1994), Erken Osmanlı Mimarlığında Çok İşlevli Yapılar : Kentsel Kolonizasyon Yapıları Olarak Zaviyeler I Öncül Yapılar: Tokat Zaviyeleri, Akademi Kitabevi, Bask1; Yeniyol Matbaası, İzmir.

Eravşar, O., (2004), Tokat Tarihi Su Yapıları (Hamamları), Arkeoloji ve Sanat Yayınları, Baskı Erman Ofset, Konya.

Erdem, H., Kişisel Fotoğraf Arşivi.

Erdemir, Y., (1986), Tokat Yöresindeki Ahşap Camilerin Kültürümüzdeki Yeri, Türk Tarihinde ve Kültüründe Tokat Sempozyumu, Temmuz, Gelişim Matbaası, Ankara, Bildiriler Kitabı, 295-312.

Erder, C., (1999), Tarihi Çevre Kaygısı, ODTÜ Mimarlık Fakültesi Yayını, Ankara.

Faroqhi, S., (1994), Osmanlı'da Kentler ve Kentliler, İstanbul Türkiye Araştırmaları 3, Numune Matbaacılık, Tarih Vakfi Yayınları, İstanbul.

Görgülü, Z., (1993), İmar Planlama, Koruma ve Plancı İlişkileri Üzerine Bir Değerlendirme, Yapı Dergisi, 137.

Güvenç, B., (1974), İnsan ve Kültür, İkinci Baskı, Remzi Kitabevi, İstanbul.

Kiper, P., (2006), Küreselleşme Sürecinde Kentlerin Tarihsel- Kültürel Değerlerinin Korunmasi; Türkiye- Bodrum Örneği, Sosyal Araştırmalar Vakfi, İstanbul.

Kuban, D., (2000), Tarihi Çevre Korumanın Mimarlık Boyutu, Birinci Baskı, YEM Yayını, İstanbul.

Kuban, D., (2002), Selçuklu Çağında Anadolu Sanatı, I. Bask1, Yapı Kredi Yayınlar1-1567, Sanat-89, İstanbul.

Kuran, A., (1969), Anadolu Medeniyetleri, I. Cilt, ODTÜ Mimarlık Fakültesi, Yayın 9, Türk Tarih Kurumu Vakfı, Ankara. 
Madran, E., (2009), Dosya-14, Tarihi Çevrenin Tarihi - Osmanlıdan Günümüze Tarihi Çevre: Tavırlar-Düzenlemeler, TMMOB Mimarlar Odası Ankara Şubesi Yayını, Ankara.

Mercan, M. ve Ulu, M., E., (2003), Tokat Kitabeleri, Türk Hava Kurumu Basımevi İşletmeciliği, Ankara.

Önal, H., (1996), Anadolu Selçuklu Türbeleri, Atatürk Kültür, Dil ve Tarih Yüksek Kurumu, Atatürk Kültür Merkezi Yayını, Sayı 91, Ankara.

Önge, M. Y., (1995), Anadolu'da XII - XIII. Yüzyıl Türk Hamamları, Vakıflar Genel Müdürlüğü Yayınları, Ankara.

Özden, P.P., (2001), Kentsel Yenileme Uygulamalarında Yerel Yönetimlerin Rolü Üzerine Düşünceler ve İstanbul Örneği, İ.Ü. Siyasal BilgilermFakültesi Dergisi, No: 23-24, (Ekim 2000- Mart 2001), İstanbul.

Özen, H. ve Akın, E.S., (2009), Rehabilitation of the Historic Urban Quarter in Tokat, Iaps-Csbe\&Housing Network, 12-16 October 2009, İstanbul.

Texier, C., (2002), Küçük Asya, Üçüncü Cilt, Enformasyon ve Dökümantasyon HizmetleriVakf1, Ankara.

Uysal, O., (1986), Tokat'taki Osmanlı Camileri, Türk Tarihinde ve Kültüründe Tokat Sempozyumu, Temmuz, Tokat, Gelişim Matbaası, Ankara, Bildiriler Kitab1, 313-364.

Yavi, E., (1986), Tokat, Baskı: Güzel Sanatlar Matbaası A.Ş., İstanbul. 